\title{
University, science and the new (and old) academic roles: inner sources of institutional resilience
}

\author{
Elizabeth Balbachevsky* \\ Vuokko Kohtamäki**
}

\begin{abstract}
This paper parallels the changes experienced by universities and science at the beginning of the new century in order to explore one relevant source of resilience and change inside the universities' institutional fabric, which is its persistent dependence on the signs and norms produced by science as a nested institution. In no small degree, science is organized according to its norms and values. Notwithstanding, it de facto exists inside the institutional environment created by the university. As such, one could argue that it is a nested institution. Our argument holds that the interplay between the institutional norms coming from the university and science gives rise to one of the more relevant sources of resilience of universities. The paper explores the soundness of these assumptions on primary data collected in a research focusing on the responses of lower-level academic unit leaders in two universities: the University of Tampere, Finland, and the University of São Paulo, Brazil. In each case, we explore the local responses to the changes engendered by autonomy as a proxy of the substantial change in the university's environment, to map how the small academic units respond to a quickly changing external environment.
\end{abstract}

Keywords: Brazil, Finland, university's resilience, nested institutions, science's institutional logics.

\footnotetext{
* University of São Paulo, São Paulo, SP, Brazil.

** University of Tampere, Tampere, Finland.
} 


\section{Universidade, ciência e os novos (e antigos) papéis acadêmicos: fontes internas de resiliência institucional}

\section{Resumo}

Este artigo traça um paralelo entre as mudanças experimentadas pelas universidades e pela ciência no início do novo século, a fim de explorar uma fonte relevante de resiliência e mudança na trama institucional das universidades, que é sua persistente dependência dos direcionamentos e normas produzidas pela ciência enquanto instituição aninhada. Em grande parte, a ciência se organiza conforme suas normas e valores. Não obstante, ela existe de fato dentro do ambiente institucional criado pela universidade. Assim, poder-se-ia argumentar que é uma instituição aninhada. Argumentamos aqui que a interação entre as normas institucionais oriundas da universidade e da ciência produz uma das fontes mais relevantes de resiliência das universidades. $\mathrm{O}$ artigo explora a validez dessas premissas com base em dados primários coletados em uma pesquisa focada nas respostas de líderes de unidades acadêmicas menores em duas universidades: a Universidade de Tampere, na Finlândia, e a Universidade de São Paulo, Brasil. Em cada caso, exploramos as respostas locais às mudanças geradas pela autonomia como proxy da mudança substancial no ambiente da universidade, para mapear como as unidades acadêmicas específicas respondem a um ambiente externo que muda rapidamente.

Palavras-chave: Brasil, Finlândia, resiliência da universidade, instituições aninhadas, lógicas institucionais da ciência.

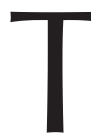
his paper parallels the changes experienced by universities and science at the beginning of the new century in order to explore one relevant source of both resilience and change inside the universities' institutional fabric, which is its persistent dependence on the signs and norms produced by science as a nested institution. When one thinks about resilience, the first image that comes to mind is the ability of something to "bounce back" and resume the former design once the external pressure is averted. In this sense, resilience helps an institution to cope, adapt, and thrive on change (Karlsen; Pritchard, 2013). As also stated by Karlsen (2013, p. 18), resilience "points to the capacity of individuals, social or technical systems to handle boundaries conditions" by sustaining the ability to prevent something dysfunctional to happens. While other conditions also concur 
with these results, institutional resilience produces a very peculiar kind of adaptability, in which an institution change while preserving its core traits. By doing so, the institution can prevent its derivation, elimination or replacement (Streeck; Thelen, 2005).

\section{Resilience and the university's resilience}

Resilience is a concept present in many disciplines, from psychology to political science, from sociology to administrative sciences. It is also employed considering different levels of analysis, from the individual up to the global one. In all these approaches, resilience refers to the ability to return to some order or normality after a crisis. That is, the subject can bounce back to its original order, form, or design (Wildavsky, 1988, p. 77). Boin and Van Eeten refer to another dimension of the concept of resilience, which is the capacity to - not only restore order - but also emerge stronger from a crisis. In the last definition, resilience is related to learning: "the ability to accommodate change" while recovering from a crisis, reconstituting a new, stronger, normality (Foster, 1993 apud Boin; Van Eeten, 2013, p. 431).

\section{The resilient university}

It is in the last sense that the concept of resilience enters into the higher education literature. In this approach, resilience links with the idea of an entrepreneurial university, "a university that actively seeks to work out a substantial shift in its organizational character to arrive at a more promising posture for the future" (Clark, 1998, p. 4). Inside the higher education literature, the concept of resilience points out to the universities' historical capability to "effectively absorb, respond to and recover from internally or externally induced set of extraordinary demands" (Karlsen; Pritchard, 2013, p. 2).

Across their long history, universities have experienced many deep crises, some of them challenging the very existence of their institutional core (Perkin, 2007). In all these events, the university bounced back renovated, 
by changing its structure, adding new roles, and forging new links with different stakeholders in the society. In the face of the present-day crisis posed by the full redesign of the university's roles in the contemporary society, some authors remember university's past resilience, described as the "universities' inbuilt capacity to respond to external demands and circumstances (..) in the context of a rather volatile external environment" (Pinheiro; Young, 2017, p. 119).

We argue that the ability to adapt to a changing environment while preserving its core traits is related to the particular pattern by which rules from two institutional logics are interweaved in the university's internal environment: the institutional logic of the university as organization and the institutional logic from science.

\section{Science as a nested institution}

Traditionally, scientists, as academics, regard themselves as members of both the "invisible colleges" that give meaning to their research and as staff of a particular university. The tensions arising from this double affiliation have been noted by the literature studying the academic profession since the middle of the XX century. Some significant contributions on this topic come from Light (1974), Ben-David (1977), Clark (1983), Becher (1987), Becher and Trowler (2001), Ruscio (1987), Altbach (1997), Enders (2001), among others. All these contributions also converge to provide evidence that increases in the academic's commitment to these large networks that knit together specialists from different organizations tend to weak their identification and commitment to the particular organization (university) where they are employed (Gouldner, 1958; Perkin, 1969; Clark, 1978). As posed by Clark (1978, p. 244), "[d]iscovery, taking place at the leadingedge specialization within each discipline, has an exceedingly high need for autonomous action".

Thus, from the perspective of the scientists, the universities should function as an arena, following the model described by Brunsson and Sahlin- 
Andersson. For them, the best scenario is the one where the institutional authorities and regulations recognize that the academic's choices are "legitimately guided by external interests, values, norms, and standards, rather than by an internally generated organizational policy" (Brunsson; Sahlin-Andersson, 2000, p. 734). In the past, the old models of university governance provided ample space for accommodating the tensions arising from this peculiar arrangement. As a de facto arena, universities had weak autonomy vis-a-vis the presence of the many "invisible colleges" organizing the university's knowledge related core activities.

However, since the end of the 1980s, the successive waves of reforms experienced by universities on a global scale present some common traits that are viewed as a threat to these gold-age arrangements. These reforms focused universities' organizational autonomy and actorhood (Enders; De Boer; Weyer, 2013; Krücken; Blümel; Kloke, 2009), reinforcing the role of institutional leaders and managers (Enders et al., 2011; Stage; Aagaard, 2019), while at the same time supporting institutional differentiation and profiling. Musselin (2007) following Brunsson and Sahlin-Andersson (2000), argued that these changes could be summarised as a process of dampening the character of the university as an arena and reconstructing it as an organization. According to Brunsson and Sahlin-Andersson, to be (re-) constructed as an organization, a social entity should, first, gain a particular identity - which means emphasizing its autonomy and establishing boundaries that will allow it to command its resources and set goals. Second, it must reinforce its internal hierarchy that would sustain the implementation of a set of coherent institutional policies. Finally, it should reinforce the particular rationality required for establishing priorities and guiding action.

In the field of higher education, the main steps of the "organizatory" reforms, adopting the term coined by Brunsson and Sahlin-Andersson (2000, p. 723), are well mapped in the bibliography (see, for example, Amaral; Jones; Karseth, 2002; Capano; Pritoni, 2019; Capano; Pritoni; Vicentini, 2019; Capano; Regini; Turri, 2016; Paradeise; Reale; Bleike; Ferlie, 2009; Shattock, 2014; Stage; Aagaard, 2019; Trakman, 2008). They include the 
strengthening of institutional autonomy, mostly understood as financial autonomy, the adoption of new funding mechanisms conditioning support to the achievement of some outputs, the introduction of measures for external assessment of quality for teaching and research, changes in internal governance, and evolving new roles of the State. As Capano (2015) points out, the changes in higher education policies are conceived as tools for making universities more efficient (achieving more by spending less) and more effective (by producing more and more diverse outputs).

Thus, one should expect that the "organisatory" reforms should weaken the understanding of the university as an arena by imposing a particular identity and rationality, and by reinforcing internal hierarchies. The literature documented some of these changes. The findings support the assumption that the reformed university has more control over the behaviors, decisions, and values of their staff (see, for example, De Boer; Enders, 2017; Finkelstein; Altbach, 2014; Frølich et al., 2013; Maassen; Stensaker, 2019). As such, these controls should also enable the universities' high hierarchies to successfully block the presence of standards, values, and norms coming from outside. However, no one ever documented this last move.

In fact, the literature recognizes that even if, for the contemporary academic, "ignoring one's institution strategy is more difficult" (Musselin, 2013, p. 28), there is also relevant evidence of the limits for these constraints, particularly regarding the ways the academics define their personal goals (Finkelstein; Jones, 2019; Henkel, 2005; Henkel et al., 2000; Meyer, 2012 Teichler; Höhle, 2013).

Today, as in the past, the academic career is supposed to mirror the prestige the academic acquired inside highly structured and hierarchized global networks of peers. Without building up her reputation inside these external networks, an academic cannot dispute a high position in the institutional career. This is particularly true if she is employed in an institution fighting for academic recognition. For the university, these invisible colleges play a critical role in assuring the quality and relevance of the knowledge created and disseminated by its academics. The only way for a university to 
build up its prestige and to strength its relative position inside the hierarchies that organized the institutional field of higher education worldwide is by promoting its academic prestige. This prestige is dependent on the name its academics can carve inside the professional networks that organize the scientific fields. We argue that the university's dependence on the prestige produced by science is the building block of the institutional resilience, i.e., the institution's capacity for bouncing back by preserving some of its core features even when facing threatening changes in its environment.

However, the links connecting academics from different institutions in the same field is also a core element of another institution: science (Polanyi, 2000 [1964]). Thus, in order to stay relevant in the global knowledge network, a university cannot prescind the parallel institutionality of science. This dependence is the main reason why preserving a degree of arena's logic inside the university's institutional fabric is strategic for any university in search of building its reputation of quality and relevance. On the other hand, preserving a degree of hybridization is a crucial element also for science to thrive as a nested institution inside the institutional field of the university. According to our argument, it is the strength of science inside the institutional fabric of the university which creates the inner mechanism allowing the university to "bounce back" when facing the challenges and threats posed by the contemporary reforms. The same mechanism also allows the university to adapt to the changing conditions produced by the waves of reform and constraints imposed by the external environment.

\section{Nested institutions}

There are two different mainstreams in the literature that works with the concept of nesting. One is the concept of nested systems, which is also related to the concept of nesting games (see Tsebelis, 1990, as a classic example); the other relates to the concept of nested regimes/institutions. In both understandings, the decision-making process inside the nested institution is supposed to be, to some degree, constrained by the rules that 
organize the high level (nesting) institution. In the same sense, the goals that different players set for the games played inside the nested institution are conditioned by the goals and decisions the same players take inside the nested institution (Argwall, 1998; Payne, 2000; Kim, 2005).

What is interesting in our example is that the hierarchical relationship between nesting and nested institutions supposed by this literature is not verified. On the contrary, the resilience effect this study tries to capture is a by-product of the countersignals produced by the games played by academics inside the nested institution - science. The superimposition of the two institutions limits the degree to which the lower-level university unities - the departments, laboratories, or research centers - blindly abide by the directives coming from the central administration. The central hypothesis advanced by this paper is that the directives enacted by the central administration receive new readings and interpretations inside the lower-level unities in order to best fit with the norms and values sustained by the cross-institutional network of peers with which the local academic group identify. A similar process happens at the individual level. Without reading the institutional directives through the lens provided by her network of peers, an academic cannot build up her reputation, which is her core asset.

Thus, as the directives lower down from the central administration toward the individual academic, they experience local reading, pruning, and interpretation. While these changes occur locally, their direction is not determined locally. On the contrary, the primary rationale which guides the reinterpretation of the organization's directives is the need for grafting its contents into the norms produced inside the broader networks of science, knitting together academics worldwide.

\section{Changes in the dynamics of higher education}

The main current historical change faced by higher education worldwide is massification. From its inception up to the 1950s, the university used to be mostly a tool for training the elites and advancing knowledge (Ben-David, 
1977). In this tradition, the merit-based selection of candidates to higher education is almost a natural consequence of the hardship of the training one should be submitted to master the intellectual capabilities that support advanced knowledge preservation and production.

The age of universal access to higher education (Trow, 2000) challenges this exclusivist ethos and pushes for universities to cater to students of diversified origins and varied educational experiences. Solidarity, including international solidarity, pluralism, cultural diversity, gender equality, and openness to the foreigners are core values incorporated into the narratives sustaining the reformed university legitimacy.

University stakeholders also demand a more proactive university in tasks related to the country's development. To fulfill this endeavor, universities are supposed to play an active role inside the national systems of innovation. They are expected to establish new links with the private corporations in order to produce and transfer economically relevant knowledge and to adapt their training programs to the needs of the market, improving the employability of their alumni. In order to respond to these pressures, universities adopted a service perspective, stressing the usefulness of its research agenda, and, in many cases, actively engaging with external actors in society, with relevant consequences for its governance model (Braun; Merrien, 1999).

These two orders of changes experienced by universities worldwide sustained the emergence of a hybrid system of values that combine elements of the elitist perspectives of the old university with the more service-oriented values. At the end of the 1990s, Clark (1998) discussed these changes and documented the birth of a new entrepreneurial ethos in some universities in Europe. As argued by Frølich et al. (2013), one possible interpretation of the recent changes experienced by the universities in its matrix of values is to view them as organizational responses to a profound reconfiguration of the shared cultural rules and meaning system that frame the organizational field of higher education. In this sense, the transformations experienced by 
higher education in the last few decades may herald a large-scale, longterm, and global institutional change.

\section{Effects of internationalization on university governance}

The spread of policies supporting university internationalization fits in the framework of changes outlined above. Internationalization answers the expectations of both the university's internal and external stakeholders. From their inception, in the 1980s, policies supporting internationalization focused mostly on expanding academic and student mobility. The central rationality behind the programs for university internationalization is exposing local academic and student communities to diverse experience in curricula design, learning practices, and research agenda and approaches, brought by the links with other academic realities abroad. For the students, this international experience is supposed to support the development of the skills necessary for facing the challenges posed by globalization and the competencies leading to the appreciation of the opportunities created by the diversity present in a closely knitted world.

For the society as a whole, a successful policy supporting university internationalization creates opportunities for tapping technological assets present in other countries and prepares the country's national innovation system to face the challenges posed by trends and developments taking place in other countries.

In the eyes of the academics, a successful policy for university internationalization creates vast opportunities for expanding and reinforcing their links with the international networks of specialists sharing the same disciplinary identity or similar research agenda. In a sense, a successful program of university internationalization tips the internal balance between locals and cosmopolitans toward the later (Gouldner, 1958) by making the local reward system more open and dependent on the signals coming from these global professional networks. The locals not only decrease in numbers. They also experience a downgrading in their status. As observed by Levinson 
already in 1989, "those locals who remain engaged with campus activities and governance might well be held in less regard by their peers and by administrators, because they have not achieved recognition as scholars comparable to that of the cosmopolitans" (Levinson, 1989, p. 24).

In a sense, thus, a successful program of university internationalization increases divisions and deepens tensions among the academics. By doing so, it contributes to making the university less like a community of scholars, and more like a multiversity, as described by Kerr (2001, p. 53): "inconsistent institutions, not one community, but several communities", where the only thing academics share in common is the parking space.

However, if the arguments presented in this paper hold, a successful policy of university internationalization is also a tool for resistance to the worse side effects of the "organizatory" reforms alluded above. As the reward system of a university opens to the signals outside the organization's control, it increases the university potential for "bouncing back" by reinforcing the arena dynamics in the institutional decision-making process, which limits the space for unilateral decisions taken by the central administration and strengthens collegiality.

\section{Changing science dynamics}

It would be easy to document the tensions arising by the interplay between science and university if the norms of science stayed preserved from change. However, the contemporary sociology of science also recognizes the extension of the changes experienced by the modes of knowledge production. Gibbons and collaborators presented the first systematic description of these changes in 1994. Their book documented the emergence of a new mode of knowledge production. A knowledge production organized in hybrid, heterarchical, and transient networks (Gibbons et al. 1994). Here, knowledge is produced in contexts of application, marked by its transdisciplinary, and counting with more reflexive and socially accountable instruments for quality control. At the time of its first publication, the 
book's central proposition produced a heated debate - for example, Van Leeuwen and Tijssen (2000) or Metzger and Zare (1999). However, the central issues addressed by this small book are still nowadays in the center lasting controversies - for example, Hessels and Lente (2008) - what is in itself a measure of its relevance.

A few years later, Etzkowitz and associates (Etzkowitz; Leydesdorff, 2000; Etzkowitz, 2011) proposed a new model for understanding the dynamics between universities, enterprises, and government. According to the triple-helix model, in the new knowledge economy, universities "play an enhanced role in innovation in increasingly knowledge-based societies" (Etzkowitz; Leydesdorff, 2000, p. 109-110). According to this model, the increased salience of knowledge and research to economic development produced a third mission to the universities, which is its active involvement with economic development. Thus, according to these authors, "A 'second academic revolution'" is "underway since World War II, but more visibly since the end of the Cold War". In the same spirit, Donald Stokes (1997) revised the traditional linear model, which organized science policies around the world since the end of World War II. The author explores the strategic roles played by research that is both focused on extending the frontiers of fundamental knowledge and guided by considerations of use (Stokes, 1997). The approaches sketched above are far from being complementary: in fact, they were developed amid intense controversies. Nevertheless, they converge in the appraisal of a significant change in the relationship between science and society, which Maasen and Olsen (2007) have called a new social contract between the academy and the society.

The first generation of these studies tended to situate the pressure for change outside the institutional fabric of science. However, Bonaccorsi and associates (see, for example, Bonaccorsi, 2008 Bonaccorsi; Daraio, 2005; Bonaccorsi; Thoma, 2007) collected relevant evidence to support the proposition that these changes are also produced and sustained by inner dynamics of science. According to these authors, the new fields of science developed at the end of the XX century partake three characteristics: first, 
they are focused on understanding complex systems, where information about the system's architecture is a crucial part of the explanation. Second, the traditional clear boundary between natural and artificial, and between basic science and engineering design is blurred. Finally, the production of new knowledge is critically dependent on access to information produced by a variety of institutions and professionals. These new fields of science require integration of heterogeneous competences and demand interaction with actors located in different institutions. Thus, the main dynamics underlining the changes experienced by science - the inter- and trans-disciplinarity, the orientation to problem-solving, and the heterogeneity of the collaboration networks - are not imposed by external dynamics. They are intrinsically produced by the changes in the core dynamics of science.

If these dynamics are internally driven or externally pushed over is a source of intense debate. Nevertheless, all literature converge in identifying the main traits of the change: the inter-, multi- and trans-disciplinary basis of knowledge production; the change in the relationship between basic/ fundamental and applied knowledge, the new linkages between knowledge and the market/economy (privatization and marketization), and the new framework imposing some degree of external regulation on knowledge production and dissemination. For Ziman (1994), among others, the critical issue is the emergence of a new scientific ethos he describes by the acronym PLACE - Proprietary, Local, Authoritarian, Commissioned, and Expert. The new ethos stands in clear opposition to the core values of the science, as described by Merton's acronym CUDOS: communalism, universalism, disinterestedness and organized skepticism (Merton, 1973).

Thus, one of the sources of the pressures for changing the institutional framework of the academic life falls within the academic community, as at least part of it tries to reform the academic rules for accommodating the needs of the new dynamics of knowledge production. 


\section{A research exercise exploring some evidence supporting the theoretical framework}

In order to map some of the dynamics sketched above, we explored data collected when implementing a research focusing on the impact of financial autonomy in the governance dynamics of universities. The main focus of the research was to explore changes experienced by universities after expanded institutional autonomy was established. To this end, the research considered the experience of two universities, the University of São Paulo (USP), Brazil, and the University of Tampere (UTA) ${ }^{1}$, Finland.

Both institutions play a central role in their respective national systems of higher education and both could be classified as research universities: $18 \%$ of USP students are enrolled at the doctoral level, and $7.9 \%$ of UTA students are enrolled at this level (data from 2016). In addition, in both institutions, collegiality was the dominant trait in the mode of governance prior autonomy, with the Rector and other academic authorities chosen in internal processes where the voice of the academic community was dominant $^{2}$. Also, the profile and degree of autonomy experienced by both universities have interesting similarities and, in both cases, autonomy was established quickly, disrupting the former status quo. Nevertheless, most importantly, the policy framework that accompanied autonomy in each institution is radically different, giving place to important changes in each university's governance. In Finland, universities were "given" modern autonomy, while, in Brazil, universities won modern autonomy as a result of a political struggle.

\footnotetext{
${ }^{1}$ Since 2019, University of Tampere merged with the Tampere Technical University, and the new name of the merged university is Tampere University (TUNI). However, we refer to UTA in this article, because the empirical data was collected from the pre-merger time.

${ }^{2}$ At the time of autonomy, USP's authorities, from the departmental level up to the Rectorship, were chosen by the members of councils where academics, and among them, the full professors dominated. It is still the same nowadays. At UTA, the rector makes all decisions concerning staff recruitments unless s/he has delegated the authority. Deans and the rector are selected by the Governing Board of the University.
} 
In Finland, university autonomy was adopted under the framework of a sectoral, national reform that produced immediate, large-scale internal governance and management impacts. Internally, autonomy generated performance orientation, accountability and centralization. As a consequence, university staff is less involved in decision-making than before, and power is concentrated in the hands of top managers.

In the Brazilian case, autonomy had fewer visible, immediate effects. Collegiality is still the dominating governance principle, and the distribution of power inside the university was less affected. Academic units preserve their identity and part of their autonomy. Nevertheless, modern autonomy required capacity-building. USP has established managerial practices convergent with the ones adopted by Finnish universities. Thus, performance evaluation and performance monitoring, resource control and centralisation are consequences of autonomy in both universities.

While the main findings of this research were published elsewhere (Kohtamäki; Balbachevsky, 2019), in this paper we explore some evidence coming from four interviews we conducted with heads of departments and laboratories inside this research project. In each university, we interviewed four heads of small academic unities, considering hard/soft and basic/applied dimensions. For this paper, we explore some lateral findings coming from these interviews that reveals the tensions experienced by academics when exposed to a competing set of rules - those emanated from the university, and those coming from their disciplinary affiliation.

According to our reasoning presented above, the general pattern we expected to find was heads of small academic unities trying to preserve local autonomy by emphasizing congruences between the disciplines' rules and the external rules coming from the university's high administration, and, at the same time, minimizing possible conflicts between these two set of norms. Our purpose in presenting the evidences collected from these interviews is just to explore the soundness of our arguments, which, of course, is in need to be tested in a full-scale dedicated research project, gathering evidences from a larger sample of university leaders under different institutional environments. 
The following table resumes some evidence collected from the interviews conducted in the two universities with heads of small academic unities (teaching programs, departments or laboratories) and presents the experience of autonomy as expressed by the academic leaders in both universities.

\section{Table 1 - Changing in the institutional environment and main responses, as experienced by academics in UTA and USP}

\begin{tabular}{|c|c|c|}
\hline & UTA & USP \\
\hline Reform effects & $\begin{array}{l}\text { Experience: new profile and brand } \\
\text { building; } \\
\text { Specifying top focus areas; } \\
\text { Recruiting those who are able to bring } \\
\text { external money; } \\
\text { Response: "outsiders cannot say what } \\
\text { should be studied". }\end{array}$ & $\begin{array}{l}\text { Experience: USP is expected to } \\
\text { compete at international ranks; } \\
\text { Recruiting focused on the ones } \\
\text { that can improve the Department/ } \\
\text { area evaluation (especially graduate } \\
\text { evaluation); } \\
\text { Response: evaluation must be done by } \\
\text { peers. Peer review preserves academic } \\
\text { quality. }\end{array}$ \\
\hline $\begin{array}{l}\text { Management: } \\
\text { evaluation } \\
\text { and new } \\
\text { performance- } \\
\text { based culture }\end{array}$ & $\begin{array}{l}\text { Less internal discussions; } \\
\text { Less transparency in decision-making; } \\
\text { Information sharing blocks; } \\
\text { Less transparency in staff } \\
\text { appointments; } \\
\text { Efficiency orientation } \\
\text { Collective efforts for defining top } \\
\text { areas; } \\
\text { Bureaucracy; } \\
\text { Internal atmosphere changed; } \\
\text { No independence to develop one's } \\
\text { teaching approaches and contents; } \\
\text { Response: more trust is needed } \\
\text { (professors know how to do their } \\
\text { work). Protect local goals, maneuver } \\
\text { to present local goals as best fit to the } \\
\text { university's goals. }\end{array}$ & $\begin{array}{l}\text { Departmental and local dynamics } \\
\text { reinforced: Department profile is } \\
\text { relevant to command institutional } \\
\text { support; } \\
\text { Collective efforts/ cooperation is } \\
\text { relevant to improve the Department / } \\
\text { Program profile; } \\
\text { Less independence to develop teaching } \\
\text { and research initiatives: research more } \\
\text { dependent on research networks; } \\
\text { Priority to well-evaluated publications. } \\
\text { Decision regarding the quality of } \\
\text { publishing outlets is externally guided; } \\
\text { Response: individual accomplishments } \\
\text { presented as collective gains. Efforts } \\
\text { for building a common goal/project for } \\
\text { unity. }\end{array}$ \\
\hline $\begin{array}{l}\text { Competition } \\
\text { orientation }\end{array}$ & $\begin{array}{l}\text { Increasing competition orientation; } \\
\text { Mechanical view of what university } \\
\text { is about } \\
\text { Short-run future; } \\
\text { Response: "professors are ready to } \\
\text { compete". }\end{array}$ & $\begin{array}{l}\text { USP is expected to compete at } \\
\text { international ranks; } \\
\text { Taking care of indicators is a central tool } \\
\text { for competition; } \\
\text { Response: search of best fit between } \\
\text { indicators and the actual work done. }\end{array}$ \\
\hline
\end{tabular}

Sources: exploratory interviews conducted by the authors with academic leaders in both universities. 
As expected, this evidence shows that academics' struggle to accommodate the norms and goals produced inside their organization with the ones that emanate from the external, disciplinary and problemoriented, networks that define their professional identity. Moreover, by doing so, they actively reinterpret the meanings for rules and goals imposed by the university's central authorities.

In both universities, academic leaders are aware of the externalization of the parameters for evaluating academic's performance. Also, in both cases, these leaders view this process with concerns. In both universities, performance is progressively expressed through "hard" indicators dependent on an external definition. Nevertheless, in both cases, performance is still dependent on the reputation the academics build up in their national and, increasingly, worldwide networks of peers. Also, in both universities, we found some evidence supporting the proposition that academic leaders actively protect the local rules and the local environment for organizing knowledge production/dissemination. There is also some evidence that rules, goals, and values enacted by the central administration receive a local interpretation in a dynamic process of matchmaking, where these rules, goals, and norms are actively framed and grafted over the local rules and norms. Thus, the stronger the links researchers sustain with the extended disciplinary or problem-oriented networks, the more intense is the processes of norm-localization (Acharya, 2004, p. 251), which end up in a "syncretic normative framework in which local influences remain highly visible".

\section{Conclusion}

The above empirical test is very preliminary and presents just a few evidences supporting our theoretical framework. More in-depth study is needed in order to provide harder tests for our assumptions. We are aware of the need of collecting more evidences from a larger set of middle level academic leaders and the need of exploring the effects of the bottom-up flow of communication, in order to access to what degree the university's 
high administration is aware of the university dependence on its academics reputation within the global science networks to branding the name of the university. It is also necessary to explore how the university high administration manage the limitation posed by science rules - as a nested institution - to their decision-making autonomy.

The central argument presented here is that the university's dependence on the reputation the academics (and academic unities) build up in extended networks is a potent source of institutional resilience. This dependence means that the ultimate goals by which the university's profile will be judged cannot be established unilaterally by the central administration but should be negotiated with the academics in general and with academic leaders in particular. One consequence of this dependence is a pressure for the university's environment to bounce back from the more managerial pressures and recognize the collegial rules in order to accommodate the goals, needs and other dynamics essential for the development of each field of knowledge. As long as the university acknowledges these limits, academics will preserve their identity as active members of the invisible colleges of peers in charge of advancing knowledge. The same move also means that the university as a whole will resist the worse effects of the organizatory reforms and preserve its identity as part of the republic of science (Polanyi, 2000 reprinted from 1964). However, considering the changes experienced by the normative sphere of science since the end of the last century, one should also consider how the inner dynamics of science are also contributing to changes of norms and values inside the universities, creating a new profile of the entrepreneurial university.

Elizabeth Balbachevsky is Doctor in Political Science and is associate professor at the Department of Political Science at the University of São Paulo.

$\triangle$ balbasky@usp.br

Vuokko Kohtamäki is Doctor in Administrative Sciences and is a senior lecturer and docent at the University of Tampere, Finland.

凶vuokko.kohtamaki@tuni.fi 


\section{References}

1. ACHARYA, Amitav. How ideas spread: whose norms matter? Norm localization and institutional change in Asian regionalism. International Organization, v. 58, n. 2, p. 239-275, 2004. https://doi.org/10.1017/S0020818304582024

2. ALTBACH, Philip G. An international academic crisis? The American professoriate in comparative perspective. Beogradski Krug, v. 3-4, n. 1-2, p. 100108, 1997.

3. AMARAL, Alberto; JONES, Glen A.; KARSETH, Berit. Governing higher education: comparing national perspectives. In: AMARAL, A.; JONES, G. A.; KARSETH, B. (Eds.). Governing higher education: national perspectives on institutional governance. London: Springer, 2002. p. 279-298.

4. ARGWALL, Vinod K. Reconciling multiple institutions: bargaining, linkages and nesting. In: ARGWALL, V. K. Institutional designs for a complex world: bargaining, linkages, and nesting. Ithaca: Cornell University Press, 1998. p. 1-31.

5. BECHER, Tony. The disciplinary shaping of the profession. In: CLARK, Burton R. (Ed.). The academic profession: national, disciplinary \& institutional settings. Berkeley: University of California Press, 1987. p. 271-303.

6. BECHER, Tony; TROWLER, Paul. Academic tribes and territories: intellectual enquiry and the culture of disciplines. London: McGraw-Hill Education, 2001.

7. BEN-DAVID, Joseph. Centers of learning: Britain, France, Germany, United States. 1. ed. New York: Mc Graw-Hill/The Carnegie Commission on Higher Education, 1977.

8. BOIN, Arjen; VAN EETEN, Michel J. G. The resilient organization. Public Management Review, v. 15, n. 3, p. 429-445, 2013. https://doi.org/10.1080/14 719037.2013.769856

9. BONACCORSI, Andrea. Search regimes and the industrial dynamics of science. Minerva, v. 46, n. 3, p. 285-315, 2008. https://doi.org/10.1007/s11024-0089101-3

10. BONACCORSI, Andrea; DARAIO, Cinzia. Exploring size and agglomeration effects on public research productivity. Scientometrics, v. 63, n. 1, p. 87-120, 2005. https://doi.org/10.1007/s11192-005-0205-3

11. BONACCORSI, Andrea; THOMA, Grid. Institutional complementarity and inventive performance in nano science and technology. Research Policy, v. 36, n. 6, p. 813-831, 2007.

12. BRAUN, Dietmar; MERRIEN, François-Xavier. Governance of universities and modernisation of the state: analytical aspects. In: BRAUN, D.; MERRIEN, F.-X. (Eds.). Towards a new model of governance for universities? A comparative view. London: Jessica Kingsley Publishers, 1999. p. 9-33.

13. BRUNSSON, Nils; SAHLIN-ANDERSSON, Kerstin. Constructing organizations: the example of public sector reform. Organization Studies, v. 21, n. 4, p. 721 746, 2000. https://doi.org/10.1177\%2F0170840600214003 
14. CAPANO, Giliberto. Understanding how and why policy design matters: the policy design dynamics of governance reforms in higher education. England, Italy and the Netherlands Compared. In: ECPR JOINT SESSIONS, April 30, 2015, Warsaw. Proceedings... Warsaw: European Consortium for Political Research, 2015.

15. CAPANO, Giliberto; PRITONI, Andrea. Varieties of hybrid systemic governance in European higher education. Higher Education Quarterly, v. 73, n. 1, p. 10-28, 2019. https://doi.org/10.1111/hequ.12180

16. CAPANO, Giliberto; PRITONI, Andrea; VICENTINI, Giulia. Do policy instruments matter? Governments' choice of policy mix and higher education performance in Western Europe. Journal of Public Policy, v. 39, p. 1-27, 2019. https://doi.org/10.1017/S0143814X19000047

17. CAPANO, Giliberto; REGINI, Marino; TURRI, Matteo. The transformation of systemic and institutional governance. In: CAPANO, G.; REGINI, M.; TURRI, M. (Eds.). Changing governance in universities. London: Springer, 2016. p. 141162.

18. CLARK, Burton R. Academic differentiation in national systems of higher education. Comparative Education Review, v. 22, n. 2, p. 242-258, 1978.

19. CLARK, Burton R. The higher education system: academic organization in cross-national perspective. 1. ed. Berkley: Univ of California Press, 1983.

20. CLARK, Burton R. Creating entrepreneurial universities: organizational pathways of transformation. Bigley, UK: Emerald Group Publishing Limited, 1998.

21. DE BOER, Harry; ENDERS, Jürgen. Working in the shadow of hierarchy: organisational autonomy and venues of external influence in European universities. In: BLEIKLIE, Ivar; ENDERS, Jürgen; LEPORI, Benedetto (Eds.). Managing universities. New York: Springer, 2017. p. 57-83.

22. ENDERS, Jürgen. Between state control and academic capitalism: a comparative perspective on academic staff in Europe. In: ENDERS, J. Academic staff in Europe: changing contexts and conditions. Westport: Greenwood Press, 2001. p. 1-24.

23. ENDERS, Jürgen; DE BOER, Harry; FILE, Jon; JONGBLOED, Ben; WESTERHEIJDEN, Don. Reform of higher education in Europe. In: ENDERS, J. et al. (Eds.). Reform of higher education in Europe. Brill Sense, 2011. p. 1-10.

24. ENDERS, Jürgen; DE BOER, Harry; WEYER, Elke. Regulatory autonomy and performance: the reform of higher education re-visited. Higher Education, v. 65, n. 1, p. 5-23, 2013. https://doi.org/10.1007/s10734-012-9578-4

25. ETZKOWITZ, Henry. Normative change in science and the birth of the triple helix. Social Science Information, v. 50, n. 3-4, p. 549-568, 2011. https://doi. org/10.1177\%2F0539018411411403

26. ETZKOWITZ, Henry; LEYDESDORFF, Loet. The dynamics of innovation: from national systems and 'Mode 2 ' to a triple helix of university-industry-government 
relations. Research Policy, v. 29, n. 2, p. 109-123, 2000. https://doi.org/10.1016/ S0048-7333(99)00055-4

27. FINKELSTEIN, Martin J.; ALTBACH, Philip G. The academic profession: the professoriate in crisis. London: Routledge, 2014.

28. FINKELSTEIN, Martin J.; JONES Glen A. Professorial pathways: academic careers in a global perspective. Baltimore: JHU Press, 2019.

29. FRØLICH, Nicoline; HUISMAN, Jeroen; SLIPERSATER, Stig; STENSAKER, Bjørn; BÓTAS, Paulo C. P. A reinterpretation of institutional transformations in European higher education: strategising pluralistic organisations in multiplex environments. Higher Education, v. 65, n. 1, p. 79-93, 2013. https:/doi. org/10.1007/s10734-012-9582-8

30. GIBBONS, Michael; LIMOGES, Camille; NOWOTNY, Helga; SCHWARTZMAN, Simon; SCOTT, Peter; TROW, Martin. The new production of knowledge: the dynamics of science and research in contemporary societies. London: Sage, 1994.

31. GOULDNER, Alvin W. Cosmopolitans and locals: toward an analysis of latent social roles. Administrative Science Quarterly, v. 2, n. 2, p. 444-480, 1958.

32. HENKEL, Mary. Academic identity and autonomy in a changing policy environment. Higher Education, v. 49, n. 1-2, p. 155-176, 2005. https://doi. org/10.1007/s10734-004-2919-1

33. HENKEL, Mary; HANNEY, Stephen; KOGAN, Maurice; VAUX, Janet; LAING, Dagmar von W. Academic responses to the UK foresight programme. Higher Education Management, v. 12, n. 1, p. 67-84, 2000.

34. HESSELS, Laurens K.; LENTE, Harro van. Re-thinking new knowledge production: a literature review and a research agenda. Research Policy, v. 37, n. 4, p. 740-760, 2008. https://doi.org/10.1016/j.respol.2008.01.008

35. KARLSEN, Jan E. Reframing university adaptation. In: KARLSEN, Jan E.; PRITCHARD, Rosalind M. O. (Eds.). Resilient universities: confronting changes in a challenging world. Bern: Peter Lang, 2013. p. 17-52.

36. KARLSEN, Jan E.; PRITCHARD, Rosalind M. O. (Eds.). Resilient universities: confronting changes in a challenging world. Bern: Peter Lang, 2013.

37. KERR, Clark. The uses of the university. Cambridge: Harvard University Press, (1967) 2001.

38. KIM, Sung C. Nested institutions and the retardation of the adaptive process. Systems Research and Behavioral Science, v. 22, n. 6, p. 483-495, 2005. https:// doi.org/10.1002/sres.660

39. KOHTAMÄKI, Vuokko; BALBACHEVSKY, Elizabeth. An explorative study of the consequences of university autonomy in Finland and Brazil. Higher Education Quarterly, v. 73, n. 3, p. 328-342, 2019. https://doi.org/10.1111/hequ.12186 
40. KRÜCKEN, Georg; BLÜMEL, Albrecht; KLOKE, Katharina (Eds.). Towards organizational actorhood of universities: occupational and organizational change within German university administrations. Speyer: German Research Institute for Public Administration, 2009.

41. LEVINSON, Richard M. The faculty and institutional isomorphism. Academe, v. 75, n. 1, p. 23-27, 1989. https://doi.org/10.2307/40249781

42. LIGHT, Donald. Introduction: the structure of the academic professions. Sociology of Education, v. 47, n. 1, p. 2-28, 1974. https://doi.org/ $10.2307 / 2112165$

43. MAASSEN, Peter; STENSAKER, Bjørn. From organised anarchy to de-coupled bureaucracy: the transformation of university organisation. Higher Education Quarterly, v. 73, n. 4, p. 456-468, 2019. https://doi.org/10.1111/hequ.12229

44. MAASEN, Peter; OLSEN, Johan P. University dynamics and European integration, v. 19. 1. ed. Dordrecht: Springer, 2007.

45. MERTON, Robert K. The normative structure of science. In: Merton, Robert K. The sociology of science: theoretical and empirical investigations. Chicago: The University of Chicago Press, (1942) 1973. p. 267-78.

46. METZGER, Norman; ZARE, Richard N. Interdisciplinary research: from belief to reality. Science, v. 283, n. 5402, p. 642-643, 1999. https://doi.org/10.1126/ science.283.5402.642

47. MEYER, Luanna H. Negotiating academic values, professorial responsibilities and expectations for accountability in today's university. Higher Education Quarterly, v. 66, n. 2, p. 207-217, 2012.

48. MUSSELIN, Christine. Are universities specific organisations? In: KRÜCKEN, Georg; KOSMÜTZKY, Anna; TORKA, Marc (Eds.). Towards a multiversity? Universities between global trends and national traditions. Bielefeld: Transcript, 2007. p. 63-84.

49. MUSSELIN, Christine. Redefinition of the relationships between academics and their university. Higher Education, v. 65, n. 1, p. 25-37, 2013.

50. PARADEISE, Catherine; REALE, Emanuela; BLEIKLIE, Ivar; FERLIE, Ewan. University governance. London: Springer, 2009.

51. PAYNE, Dexter C. Policy-making in nested institutions: explaining the conservation failure of the EU's common fisheries policy. JCMS: Journal of Common Market Studies, v. 38, n. 2, p. 303-324, 2000. https://doi. org/10.1111/1468-5965.00221

52. PERKIN, Harold. Key profession: the history of the Association of University Teachers. London: Routledge Publishers, 1969.

53. PERKIN, Harold. History of universities. In: FOREST, James J.; ALTBACH, Philip. G. (Eds.). International handbook of higher education. London: Springer, 2007. p. 159-205. 
54. PINHEIRO, Rómulo; YOUNG, Mitchell. The university as an adaptive resilient organization: a complex systems perspective. In: HUISMAN, Jeroen.; TIGHT, Malcolm (Eds.). Theory and method in higher education research. Melbourne: Emerald Publishing Limited, 2017. p. 119-136.

55. POLANYI, Michael. The republic of science: its political and economic theory. Minerva, v. 38, n. 1 p. 1-21, 2000.

56. RUSCIO, Kenneth P. The distinctive scholarship of the selective Liberal Arts College. The Journal of Higher Education, v. 58, n. 2, p. 205-222, 1987. https:// doi.org/10.1080/00221546.1987.11778240

57. SHATTOCK, Michael. International trends in university governance: autonomy, self-government and the distribution of authority. London: Routledge, 2014.

58. STAGE, Andreas K.; AAGAARD, Kaare. Danish universities under transformation: developments in staff categories as indicator of organizational change. Higher Education, v. 78, n. 4, p. 629-652, 2019. https://doi.org/10.1007/ s10734-019-00362-y

59. STOKES, Donald E. Pasteur's quadrant: basic science and technological innovation. Washington DC: Brookings Institution Press, 1997.

60. STREECK, Wolfgang; THELEN, Kathleen A. Beyond continuity: institutional change in advanced political economies. Oxford: Oxford University Press, 2005.

61. TEICHLER, Ulrich; HÖHLE, Ester A. The academic profession in 12 European countries - the approach of the comparative study. In: TEICHLER, Ulrich; HÖHLE, Ester A. (Eds.). The work situation of the academic profession in Europe: findings of a survey in twelve countries. London: Springer, 2013. p. 1-11.

62. TRAKMAN, Leon. Modelling university governance. Higher Education Quarterly, v. 62, n. 1-2, p. 63-83, 2008.

63. TROW, Martin. From mass higher education to universal access: the American advantage. Minerva, v. 37, n. 4, p. 303-328, 2000.

64. TSEBELIS, George. Nested games: rational choice in comparative politics. Berkeley, CA: University of California Press, 1990.

65. VAN LEEUWEN, Thed; TIJSSEN, Robert. Interdisciplinary dynamics of modern science: analysis of cross-disciplinary citation flows. Research Evaluation, v. 9, n. 3, p. 183-187, 2000. https://doi.org/10.3152/147154400781777241

66. WILDAVSKY, Aaron B. Searching for safety. v. 10. Piscataway: Transaction Publishers, 1988.

67. ZIMAN, John M. Prometheus bound. Cambridge: Cambridge University Press, 1994.

Received: 8 Jan. 2020. Approved: 12 June 2020. 


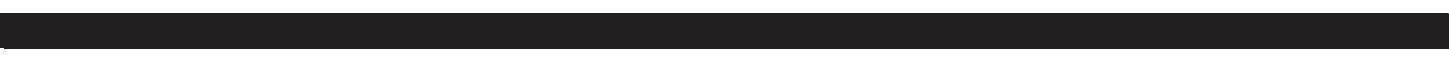

